\title{
LA REGULAGIÓN DE LOS ESTEREOTIPOS DE GÉNERO EN LA PUBLICIDAD: EL ROL DE LA PERSUASIÓN EN EL REFUERZO DE LA DESIGUALDAD*
}

\author{
María Guadalupe Martínez Alles***
}

\begin{abstract}
Resumen
La publicidad es información que tiene por objetivo persuadir. El fenómeno publicitario conecta al proveedor profesional (creador) y al consumidor (receptor) bajo particulares dinámicas de mercado y en el marco de un contexto social y cultural determinado que revela la complejidad y significancia del acto de consumo. Sin embargo, la regulación de la publicidad ha estado mayormente centrada, por un lado, en el deber de información del proveedor profesional y, por el otro, en el acceso a la información del consumidor. En este artículo argumento que para poder dimensionar el alcance del impacto del fenómeno publicitario en nuestra sociedad y, en particular, de la publicidad que contiene estereotipos de género, debemos abandonar aquellas representaciones simplificadas de la publicidad como información, del proveedor profesional como informante y del consumidor como soberano informado. Estas representaciones que prescinden por completo del contexto difícilmente puedan ayudarnos a repensar la regulación de la publicidad actual y a proponer respuestas desde el derecho que sean más sensibles a su faz persuasiva y así más adecuadas para lidiar con el problema de la publicidad estereotipada en nuestra sociedad.
\end{abstract}

Palabras clave: publicidad, estereotipos de género, publicidad abusiva, sesgos cognitivos, manipulación en el mercado, publicidad persuasiva, impacto subliminal, identidad de género, igualdad de género.

\section{INTRODUGGIÓN}

La regulación de la publicidad ha sido generalmente abordada desde la perspectiva de su creador, con el acento en el deber de información que recae sobre el proveedor profesional de suministrar al consumidor en forma cierta, clara y detallada todo lo relacionado con las características esenciales de los bienes y servicios que provee

\footnotetext{
* Agradezco a Pamela Tolosa por su generosa invitación a participar del Programa de Género, Igualdad y Derecho de la Universidad Nacional del Sur (Bahía Blanca, Argentina), trabajo del cual se desprenden algunas partes de este artículo, y a revisores anónimos, por sus interesantes sugerencias y comentarios. Agradezco particularmente a Ariana Kissner por su excelente asistencia de investigación. Por supuesto, los errores y defectos que todavía quedan son de mi exclusiva responsabilidad. Todas las traducciones del inglés me pertenecen.

** Universidad de San Andrés, Buenos Aires, Argentina (mguadamartinez@gmail.com). Artículo recibido el 22 de junio de 2019, y aceptado para su publicación el 1 de agosto de 2019.
} 
y las condiciones de su comercialización. En relación al receptor de la publicidad, la regulación ha puesto el foco en el acceso a la información del consumidor y ha ofrecido generalmente herramientas de protección de aquel frente a supuestos de publicidades falsas, engañosas o abusivas que puedan inducirlo a error sobre el producto o servicio en cuestión, es decir, para aquellos supuestos en que haya tenido lugar una violación al deber de información que le corresponde al proveedor profesional.

Se advierte así que, desde el derecho, la publicidad es sobre todo concebida como información, y el consumidor, como el agente racional que procesa cuidadosamente dicha información para arribar a las decisiones de consumo que le resulten más beneficiosas, y que solo amerita protección frente a información falsa, engañosa o abusiva que lo lleve a error sobre los elementos esenciales de la contratación. Es decir, el foco se centra, por un lado, en si el proveedor ofrece la información debida y, por el otro, en si el consumidor tiene suficiente acceso a esa información.

Esta perspectiva solo puede brindar una mirada parcializada del comportamiento del proveedor y del consumidor, y del impacto de la publicidad en el último. Esta particular manera de abordar la problemática de la publicidad no solo desconoce la complejidad propia de las dinámicas de mercado y del comportamiento del consumidor, sino que también ignora la manera en la que proveedores profesionales y consumidores se relacionan entre sí en dicho contexto. Por un lado, soslaya que el proveedor profesional, más que informar al consumidor, persigue principalmente el objetivo de colocar su producto o servicio en el mercado y captar al mayor número de consumidores posible. En otras palabras, lo que el proveedor busca es más bien persuadir al consumidor de las bondades y beneficios del producto que ofrece, para mantenerse competitivo, y para ello, invierte recursos y esfuerzos en comprender el comportamiento de aquel. Por el otro, la perspectiva que estamos analizando, promueve una acotada noción, principalmente económica, del consumidor como el actor racional que procesa información y solo busca consumir para satisfacer sus necesidades individuales ("consumidor soberano"), sin advertir que el consumidor padece de sesgos cognitivos que afectan sus decisiones de consumo, y que el acto de consumo sucede en un contexto cultural determinado y tiene un significado para aquel que va más allá de la acción de consumir en sí misma ("consumidor situado socialmente").

De todo ello se desprende que, para poder dimensionar el alcance del impacto del fenómeno publicitario en nuestra sociedad y, en particular, de la publicidad que contiene estereotipos de género, debemos abandonar aquellas representaciones simplificadas de la publicidad como información, del proveedor profesional como informante y del consumidor como soberano informado. Estas representaciones que prescinden por completo del contexto difícilmente puedan ayudarnos a repensar la regulación de la publicidad actual y a proponer respuestas desde el derecho que sean más adecuadas para lidiar con el problema de la publicidad estereotipada en nuestra sociedad.

La estructura del artículo es la siguiente. La Sección II da cuenta de las dinámicas propias del contexto de mercado en el que se desarrolla el acto de consumo, que se presenta como un acto comunicativo complejo inseparable del fenómeno publicitario. Siguiendo las enseñanzas de la literatura en economía del comportamiento y en psicología social, se exploran a lo largo de esta Sección las particularidades propias del comportamiento del consumidor (i. e., sesgos cognitivos, influencia del contexto 
social) y del proveedor profesional (i. e., explotación de los sesgos cognitivos del consumidor en su beneficio), la relación que establecen entre sí, con el mercado mismo y con la publicidad, en particular, con la publicidad estereotipada. Sobre la base de estas observaciones, la Sección III problematiza el entendimiento clásico de la publicidad como información y hace evidente la preponderancia de su faz persuasiva. En esa línea, la Sección presenta evidencia de la influencia de la publicidad en los estereotipos de género que rigen a una sociedad, y del impacto subliminal que la misma genera en el bienestar general y en la autonomía individual de sus receptores. La Sección IV ofrece un análisis crítico de las respuestas clásicas del derecho a la regulación de la publicidad como información y propone alternativas regulatorias más sensibles a su función persuasiva en general, y en particular, respecto de los estereotipos de género. A tal fin, se hace especial, aunque no exclusiva, referencia a la regulación de la publicidad en Argentina con la simple pretensión de ilustrar una problemática que se manifiesta de similar manera a nivel regional y global. La selección del caso argentino se explica por el movimiento importante para la remoción de los estereotipos de género recientemente experimentado allí por parte del Estado, de la sociedad civil y de las organizaciones sociales, y por el reciente Anteproyecto de Reforma de la Ley de Defensa del Consumidor (2018) que de algún modo da cuenta de ello al proponer una regulación novedosa que muestra cierta sensibilidad hacia la perspectiva de género en el ámbito de las relaciones de consumo. La Sección V concluye sucintamente.

\section{LAS DINÁMIGAS DEL MERGADO}

A los fines de entender el fenómeno publicitario y sus alternativas regulatorias, parece necesario comprender primero la relación que los actores relevantes del mercado mantienen entre sí, con el mercado mismo y con la publicidad. Así, se analizará, por un lado, el comportamiento del consumidor, en su calidad de receptor de la publicidad, como agente imperfectamente racional que toma decisiones de consumo en un contexto social determinado; y, por el otro, el comportamiento del proveedor profesional de bienes o servicios como creador de la publicidad, y su relación con la necesaria manipulación que tiene lugar en el mercado.

\subsection{El comportamiento del consumidor: Sesgos cognitivos y contexto social}

La fuerza de la evidencia empírica permite comprender que, comúnmente, a la hora de tomar decisiones, las personas no se comportan como un homo economicus o un agente perfectamente racional. ${ }^{1}$ Por el contrario, como agentes imperfectamente racionales, se desvían de lo que la teoría de la decisión racional predice. Las personas tenemos una racionalidad limitada (bounded rationality), debido a que nuestras habilidades cognitivas no son infinitas. ${ }^{2}$ Esto implica que en ciertos contextos podamos comportarnos acorde a los postulados que la economía históricamente ha asumido. También, implica que a veces nos desviemos de ese modelo, que actuemos en base a atajos mentales y a procesos cognitivos alternativos que no se relacionan con la lógica

1 Jolls et al. (1998).

2 Jolls et al. (1998), p. 1.477. 
o con estándares de decisión racional. Los responsables de este comportamiento son las heurísticas del pensamiento intuitivo y los sesgos cognitivos. ${ }^{3} \mathrm{Al}$ momento, existe un numeroso catálogo de sesgos cognitivos identificados por psicólogos y economistas a partir de experimentos e hipótesis planteadas, como por ejemplo, disponibilidad, confirmación, status quo y arrastre, entre otros. ${ }^{4}$

Por el sesgo del status quo, tendemos a mantener el estado actual de cosas y creemos que la alternativa por defecto se tomó por alguna razón ya consensuada, instalada o aceptada en sociedad, nos adaptamos a ella y hacemos poco esfuerzo por cambiarla incluso frente a alternativas más ventajosas. ${ }^{5}$ Por su parte, el sesgo de arrastre puede verse cuando tratamos de hacer algo y lo fundamentamos en el hecho de que otros también lo hacen. ${ }^{6}$ Este sesgo es muy común sobre todo en la adolescencia, cuando la necesidad de inclusión y de aceptación en el grupo conduce a imitar las actitudes y conductas de los demás (p. ej., seguir una moda que sigue el resto de nuestras compañeras). En relación a los estereotipos de género, el sesgo del status quo explica nuestra tendencia a mantener y adoptar las creencias generalizadas acerca de los roles y características específicas de cada género arraigadas en nuestra sociedad. Por su parte, el sesgo de arrastre explica cómo los niños, las niñas, los adolescentes y también las personas adultas son víctimas del "querer pertenecer", sucumben ante la presión y el control social para no quedar aislados, e intentan atenerse a los estándares de belleza como así también respetar y vivir acorde a las expectativas instaladas sobre lo femenino y lo masculino. Dichos sesgos cognitivos que nos convierten en vulnerables dan cuenta de los desafíos con los que nos enfrentamos a diario a la hora de tomar decisiones de consumo.

Daniel Kahneman explica que la mente humana tiene dos modos de pensamiento: el Sistema 1 y el Sistema 2. ${ }^{7}$ Ambos están presentes todo el tiempo, aunque siempre que uno es el protagonista, el otro se mantiene en estado de latencia. El Sistema 1 funciona casi silenciosamente y comprende toda aquella actividad que se realiza de modo irreflexivo. Por el contrario, el Sistema 2 alude a todo aquello que no hacemos de forma espontánea, sino de manera deliberada y con esfuerzo. De esa manera, el Sistema 1 refiere al pensamiento rápido e intuitivo. Comprende, en general, todas las operaciones mentales que realizamos de manera automática: heurísticas, actividad mental intuitiva e intuición experta. Por su parte, el Sistema 2 se distingue por administrar una forma lenta y esforzada de pensar. Así, refiere a todo aquello que no se realiza de manera intuitiva, sino solo con atención y concentración. Por ejemplo, activamos el Sistema 2 para leer textos complejos o realizar un cálculo matemático.

En el día a día, normalmente, el Sistema 1 funciona en piloto automático y el Sistema 2 está en modo de mínimo uso. ${ }^{8}$ La atención es un recurso escaso y no tiene

3 Heuristics and biases es un concepto originalmente propuesto por TVERsky y KAHNEMAN (1974). Véase más en Kahneman (2011), Korobkin y Ulen (2000), Rachlinski (2011).

4 Jolls et al. (1998).

5 Véase Kahneman et al. (1991), pp. 197-199.

6 Kahneman et al. (1991), pp. 197-199.

7 Kahneman (2011), pp. 19-58.

8 Kahneman (2011), pp. 24-25. 
sentido usarla si la actividad a realizar verdaderamente no requiere esfuerzo. Como el Sistema 2 es deliberado, no lo activamos si lo que hacemos nos resulta fácil y cómodo. ${ }^{9} \mathrm{El}$ problema es que, a veces, por nuestros sesgos y heurísticas, cometemos el error de creer que no necesitamos activarlo. Así, el Sistema 2 solo en ocasiones toma las riendas de nuestra mente y el Sistema 1 suele predominar, de manera casi inconsciente, con muy poco o ningún esfuerzo. Es mucho más protagonista e influyente de lo que pensamos y de lo que nos gustaría asumir. A pesar de estos datos, la mayoría de nosotros se identifica con el Sistema 2. Cuando pensamos en nosotros mismos, pensamos en alguien racional, consciente, que decide qué pensar y qué hacer. ${ }^{10}$ Aunque la confianza en nuestra intuición está justificada, pues la mayoría de nuestras corazonadas y acciones son apropiadas la mayor parte del tiempo, nos asumimos de una manera que no se condice con la realidad de cómo pensamos y cómo decidimos. La narrativa de una persona racional nos queda más cómoda que admitir que tomamos la mayoría de nuestras decisiones de consumo de manera intuitiva y bajo la influencia de sesgos cognitivos. ${ }^{11}$ Adicionalmente, la lógica del Sistema 2, que define a un ser racional, pensante y autónomo, construye una narrativa coincidente con el eje de nuestro sistema jurídico: la autonomía de la voluntad.

En este proceso, hay un aspecto más que no podemos soslayar: el consumidor debe satisfacer sus preferencias de consumo en un contexto cultural determinado. De hecho, según Douglas Kysar, el contexto social afecta las preferencias, las creencias, los valores y los estilos de vida de los consumidores y ese contexto es a la vez moldeado por las propias decisiones de los productores y de los consumidores (p. ej., por el creador de publicidad que propone ideales de cuerpos femeninos inalcanzables asociados a una determinada marca o producto). ${ }^{12}$ Esto parece indicar que el acto de consumo es algo bastante más complejo que la mera satisfacción de necesidades individuales de aquel consumidor racional. ${ }^{13}$

De acuerdo con Kysar, el "acto de consumo es un acto comunicativo complejo que combina la búsqueda de placer con elementos de autodefinición como personas y expresión social". ${ }^{14}$ El consumidor define sus valores, aspiraciones, expectativas e identidades en referencia a los productos que consume (p. ej., un estilo de indumentaria, determinados productos de belleza, una marca o tipo de auto, etc.) y a las actividades de esparcimiento que realiza (p. ej., jugar al fútbol, hacer boxeo, practicar baile o

9 Kahneman (2011), p. 23.

10 Kahneman (2011), p. 21.

11 Kahneman (2011), p. 52 (argumentando que "la idea de que nuestro entendimiento de cómo funciona nuestra mente es limitado es difícil de aceptar porque, naturalmente, es extraño a nuestra experiencia, pero es verdadero: sabemos mucho menos acerca de nosotros mismos que lo que creemos").

12 Kysar (2002), p. 858.

13 KYSAR (2002), p. 857 (argumentando que "el debate acerca de la protección legal de los consumidores tiende a ser acerca del poder de mercado, la minimización de costos y el acceso a la información, sin prestar atención al acto de consumir como un evento que tiene significancia que va más allá de la mera satisfacción de necesidades individuales").

14 KYSAR (2002), p. 890. 
danza, etc.). El consumidor generalmente no elige cualquier producto, sino aquel que tiene un significado para él, y a la vez ese significado es definido por el creador del producto, por sus usuarios o por quienes afectan la significancia social de dicho producto. ${ }^{15}$

De esta manera, nuestras preferencias de consumo son de algún modo construidas socialmente: es decir, los productores construyen, por ejemplo, estilos de vida de varones y mujeres e ideales de cuerpos que, en parte, definen nuestros deseos o preferencias como consumidores. De acuerdo con Kysar, ello no significa que los consumidores sean incapaces de resistir la influencia social ni que sus preferencias sean siempre mediadas por los proveedores que imprimen un cierto significado social a sus productos, sino más bien que consumidores y proveedores nos encontramos entrelazados en un constante proceso de definición y redefinición, ya que el contexto social mismo es construido en base a nuestros propios aportes. ${ }^{16}$

De allí que una noción del consumidor como aquel que padece sesgos cognitivos que lo vuelven absolutamente vulnerable y sujeto a constante manipulación por parte de los proveedores no sea del todo atendible, ya que desconoce que la construcción del contexto social en el que se toman decisiones de consumo no es exclusiva del proveedor sino que se nutre también de los propios aportes de los consumidores. También parece claro a esta altura que una noción del consumidor como actor racional que procesa información adecuadamente para satisfacer sus preferencias individuales es de lleno insatisfactoria. Solo un entendimiento más rico del acto de consumir y lo que ello implica - publicidad-, que pueda dar cuenta de que las preferencias de consumo deben ser satisfechas en un contexto social y cultural determinado, nos podrá brindar una mirada más realista del comportamiento del consumidor y su significado. Esto nos permitirá comprender mejor el impacto de la publicidad en general y, en particular, en la reproducción, refuerzo y perpetuación de estereotipos de género en nuestra sociedad.

\subsection{El comportamiento del proveedor profesional: Explotación de sesgos cognitivos}

El desequilibrio es la característica representativa de una relación de consumo. ${ }^{17}$ Además de la asimetría de poder de negociación y de información, otra dimensión de la desigualdad que distingue el vínculo proveedor-consumidor refiere al desbalance en que se encuentra el consumidor debido a su vulnerabilidad cognitiva: toma decisiones bajo un preponderante Sistema $1 .{ }^{18}$ Este vínculo experto-profano despliega su influencia en todos los aspectos de la relación contractual, incluida la publicidad. Los proveedores invierten recursos y esfuerzos en conocer los sesgos cog-

15 Kysar (2002), p. 892. Por ejemplo, se observa un entendimiento generalizado de que consumir cosméticos o cremas antiarrugas es de "mujeres", mientras que elegir el tipo de auto a comprar es de "varones".

16 KYSAR (2002), p. 894.

17 BaR-GILL (2014).

18 Kahneman (2011). 
nitivos de los consumidores (utilizando, por ejemplo, técnicas de neuromarketing) más que los consumidores mismos, lo que agrava la asimetría referida. ${ }^{19}$ Además, los proveedores en mercados competitivos que no estén dispuestos a explotar las limitaciones cognitivas de los consumidores serán desplazados por aquellos que sí estén dispuestos a hacerlo: así, de acuerdo con Jon Hanson y Kysar, la manipulación se vuelve un requisito inevitable para mantenerse en un mercado competitivo. ${ }^{20}$

De acuerdo con George Akerlof y Robert Shiller, la publicidad es uno de los campos más fértiles para atrapar phools. ${ }^{21}$ Phools son aquellos consumidores que, por cómo funciona la mente humana y por su forma de pensar, son manipulados para hacer algo en interés del phisherman y no según su propio interés, y toman una decisión que no les conviene. ${ }^{22}$ La mente humana piensa de forma natural en términos narrativos. ${ }^{23}$ Así, existen historias que las personas se cuentan a sí mismas, que desempeñan un papel en sus decisiones. En ese sentido, el desarrollo de la publicidad puede tener que ver con el desarrollo en las distintas maneras de contar historias. ${ }^{24}$ Nuestras decisiones de mercado dependen de nuestras narrativas, y también de la influencia que ejercen otros sobre esas narrativas para servir a sus propósitos. ${ }^{25} \mathrm{La}$ publicidad es exitosa toda vez que la narrativa propuesta en el anuncio se injerta en la narrativa propia del consumidor. ${ }^{26}$ El trabajo de los publicistas es intervenir en esas narrativas para lograr sus fines: incrementar ventas.

En ese proceso de convencer y persuadir, los estereotipos de género son utilizados por los publicistas como una herramienta más para instalar sus productos. Direccionar ciertas imágenes (p. ej., de ideales de belleza femeninos, del rol preponderante de las mujeres en las tareas de cuidado de la familia o en actividades domésticas, etc.) a ciertos grupos de consumidores (p. ej., mujeres) no es simplemente una respuesta a las características ya existentes en ese grupo, sino que es también una confirmación, refuerzo y redefinición de esas características. Es una especie de

19 Véase Akerlof y Shiller (2015), pp. 52-54 (describiendo cómo los publicistas usan, mediante el ensayo y error, técnicas persuasivas para asegurar e incrementar las ventas de sus productos). El neuromarketing es el estudio del comportamiento de los consumidores que se sirve de técnicas neurocientíficas a fin de obtener datos de la conducta de consumo y de los hábitos de una persona. Por ejemplo, se utilizan cámaras, sensores y pulseras para registrar expresiones, los cambios en el habla y hasta el ritmo cardíaco del consumidor.

20 Véase Hanson y Kysar (1999) (quienes se concentran en la industria del cigarrillo como un ejemplo paradigmático de estrategias de manipulación en el mercado).

21 Akerlof y Shiller (2015), pp. 1-11.

22 Akerlof y Shiller (2015), pp. xi-xii.

23 Akerlof y Shiller (2015), p. 46.

24 Akerlof y Shiller (2015), pp. 47-52 (describiendo tres ejemplos históricos de narrativas publicitarias exitosas del siglo veinte).

25 Akerlof y Shiller (2015), p. x (argumentando que "en la medida en que tengamos debilidades en saber lo que realmente deseamos, y también en la medida en que esas debilidades puedan ser rentablemente generadas y alimentadas, los mercados aprovecharán la oportunidad de incidir en esas debilidades").

26 Akerlof y Shiller (2015), p. 53. 
dinámica de retroalimentación que termina perpetuándolas: la marca refuerza cierto ideal de belleza o cierto rol social que resuena o se condice con nuestro estilo de vida, nuestras creencias y nuestras actitudes. Y a la vez, nuestras aspiraciones y estima personal se ven sutilmente moldeadas y limitadas por el contexto social. Por ejemplo, las publicidades que representan a la mujer como principal encargada de las tareas del hogar y el cuidado de la familia ejercen cierta influencia en la construcción de las aspiraciones de inserción de las mujeres en el mundo del trabajo, que aparece representado como mayormente masculino. En el mismo sentido, las publicidades que representan ideales femeninos de belleza que son inalcanzables ejercen influencia desde muy temprana edad en la estima personal de niñas y adolescentes, y en las expectativas de lo femenino que se construyen a su alrededor.

El proveedor es consciente de que a través de la publicidad imprime un significado a su producto (i. e., estilos de vida, actitudes, creencias, etc.) que el consumidor capta y asocia al mismo. En consecuencia, el proveedor tiene interés en preservar y cultivar ese significado (o narrativa) que atrae a los consumidores de su producto en ese particular contexto social. De todo ello se infiere que, si bien no podemos condenar exclusivamente a la publicidad por los estereotipos de género que se encuentran arraigados en nuestra sociedad, tampoco podemos considerarla inocua ya que, como veremos, cumple un rol fundamental en la reproducción, el refuerzo y la perpetuación de esos estereotipos.

\section{COMPRENDIENDO LA PUBLICIDAD: ENTRE INFORMAGIÓN Y PERSUASIÓN}

A lo largo de todo el siglo XX, durante el cual se desarrollaron las modernas relaciones de consumo, la publicidad se configuró como un elemento para incrementar las ventas. ${ }^{27}$ Servía para promocionar el producto, en tanto le acercaba al consumidor información sobre sus características y modos de uso. ${ }^{28}$ Es decir, si bien la publicidad originalmente surgió para acercar información al consumidor sobre riesgos, uso y características del producto o servicio ofrecido, siempre tuvo su componente persuasivo para convencer y generar compradores. ${ }^{29} \mathrm{~A}$ decir verdad, la frontera entre informar y persuadir ha sido desde sus comienzos una línea delgada que ha ido variando conforme han ido cambiando las necesidades de los actores relevantes del mercado y los contextos sociales en que se desarrollan sus estrategias de venta. De hecho, a medida que las dinámicas de mercado y las nuevas tecnologías se complejizaron, el elemento persuasivo de la publicidad fue adquiriendo mayor protagonismo por sobre el aspecto informativo. ${ }^{30}$

27 Véase LoRenzetTi (2009), p. 156 (“el consumidor, en muchos casos no compra porque necesita ni es la necesidad la que crea la oferta; es a la inversa, la oferta crea la necesidad. Se compra porque se vio una buena publicidad, porque se desea un estatus particular al que va asociado el producto").

28 Véase Kemelmajer de Carlucai (1996), p. 141 (expresando que "la publicidad es lo que atrae al usuario o consumidor potencial; entra, penetra, es internalizada, puesto que usa una técnica de captación, de sugestión y convencimiento; el bien o servicio se quiere sobre la base de lo mostrado, de lo escuchado, percibido por esta vía, por los sentidos").

29 Véase Kuenzler (2017), pp. xvii-xxi (mostrando cómo la publicidad desde sus orígenes tuvo un doble propósito de informar y persuadir).

30 Véase Mik (2017) (analizando el fenómeno de la publicidad persuasiva a través de la web). 
Hoy en día y cada vez más, gracias a internet, a las redes sociales, a las nuevas formas de publicidad que hacen uso de influencers y youtubers, y al direccionamiento a través de plataformas online, la publicidad es menos información y más persuasión. Los publicistas apelan a las debilidades cognitivas de los consumidores para orientar su comportamiento de manera que les resulte beneficioso para su negocio. ${ }^{31}$ De hecho, estos nuevos formatos de publicidad se caracterizan por personalizar el target: se apunta directamente al Sistema 1 de los consumidores individuales específicos, para persuadirlos mediante la empatía, al acercarles experiencias y vivencias que logran insertarse fácilmente en sus narrativas mentales. ${ }^{32}$ Los consumidores se ven influidos por las historias de los anuncios y también participan de las narrativas creadas por las compañías de marketing. ${ }^{33}$ A través de pequeños relatos, la publicidad nos sugerirá, con diversos grados de sutileza - y muchas veces, perdiendo este atributo-, cómo somos o debemos ser de acuerdo a nuestra clase social, nuestra edad y nuestra condición de género. ${ }^{34}$

\subsection{La publicidad y los estereotipos de género: Impacto subliminal}

Además de convencer para comprar, la publicidad está diseñada para enviar mensajes específicos a los consumidores, que en la mayoría de los casos son intangibles y tienen un impacto subliminal. La fuerza de la evidencia empírica muestra que las publicidades influyen en los estereotipos de género que rigen a una sociedad: los refuerzan, los confirman, los reproducen, los acentúan, los perpetúan. ${ }^{35}$ Los estereotipos de género son creencias generalizadas acerca de los roles y las características específicas que recaen sobre las personas en virtud de ser varón, mujer o cualquier otra identidad no binaria. ${ }^{36}$ Los medios de comunicación, y en especial la televisión, son un instrumento poderoso en la creación de estos estereotipos y en el fortalecimiento de las expectativas sociales que pesan sobre ellos. Contribuyen a que estas creencias sean entendidas por la audiencia como algo objetivo, verdadero, incuestionable y permanente. De esta forma, se reproducen y afianzan creencias rígidas de la sociedad.

La publicidad reproduce y refuerza estereotipos de género presentes en la sociedad para captar al consumidor. En el fondo, los publicistas buscan que los productos anunciados se asocien con valores culturales con los cuales el espectador se siente cómodo. Los anuncios se diseñan tomando la máxima ventaja de las fantasías, los mitos y los miedos particulares de cada género. ${ }^{37}$ Por lo tanto, se diseñan y se construyen estereotipos de acuerdo al género de las audiencias previstas (p. ej., las publicidades de productos de limpieza en su abrumadora mayoría representan a mujeres

31 Véase Davidson (2017) (describiendo cómo los publicistas usan Facebook y otras plataformas online para direccionar publicidad a adolescentes en momentos en que se encuentran vulnerables).

32 Véase Susser et al. (2018) (quienes analizan las prácticas de manipulación facilitadas por las nuevas tecnologías de la información).

33 Akerlof y Shiller (2015), p. 53.

34 Faur y Medan (2010).

35 Véanse los estudios citados a lo largo de esta sección.

36 SANTORO (2018).

37 Craig (1992), p. 199. 
realizando las tareas del hogar y mostrando cómo el producto en cuestión hará su vida más fácil; las publicidades de automóviles están dirigidas a hombres y focalizan en mostrar modelos femeninos asociados al rodado y las características técnicas que interesan mayormente a ese público, etc.). ${ }^{38}$

La publicidad es una de las tantas fuentes de insumos para la construcción de sentidos sociales. ${ }^{39}$ Como los medios de comunicación en general, la publicidad ayuda a establecer las fronteras de lo principal, lo legítimo, lo "normal" y lo "discutible". A la vez que decide qué es relevante, clausura, silencia o invisibiliza a otros actores, a otros planes de vida, a otras posibilidades de pensar o dar cuenta de la realidad. ${ }^{40}$ La publicidad alecciona sobre la vida privada. La publicidad, según Sonia Santoro, funciona como un espejo de la sociedad en la que vivimos, refuerza representaciones del mundo -particularmente por el factor repetición- y actúa como agente socializador, al establecer los valores, los hábitos y las tendencias que cada persona debe seguir para integrarse. ${ }^{41}$ Las publicidades generalmente transmiten imágenes de lo femenino y lo masculino, como así también de las expectativas que se ponen sobre mujeres y varones, e influyen de ese modo en cómo se desarrolla el plan de vida de las personas y en cómo socializan. ${ }^{42}$

De acuerdo con Jordi González y Paredes ${ }^{43}$ si observamos las características de las relaciones de género representadas en la publicidad, advertimos los siguientes aspectos: (i) parecen representar a todos los miembros de la sociedad debido al hecho de que son de difusión pública; (ii) los individuos representados parecen aceptar estas relaciones y así validan los roles descriptos; (iii) se retratan roles y actitudes de hombres y mujeres en sociedad que definen expectativas sociales y también sirven para educar al espectador en cuanto a comportamientos aceptables e inaceptables; (iv) se desarrolla un modelamiento de nuestro mundo social; y (v) a través de la trasmisión constante y sistemática de los estereotipos de género, se contribuye a que estas creencias sean entendidas por la audiencia como algo objetivo, verdadero, incuestionable y permanente, es decir, se contribuye a la naturalización de las creencias.

Diferentes estudios empíricos que se han ocupado de analizar el contenido de la publicidad dirigida al público adulto e infantil revelan patrones de representaciones estereotipadas de hombres y mujeres. ${ }^{44}$ Así, muestran cómo la mujer adulta es

38 Para la relación entre Inteligencia Artificial (IA) y estereotipos de género, véase Specia (2019) (manifestando que Unesco reportó que Alexa y Siri refuerzan problemáticos estereotipos de género al utilizar nombres femeninos y voces femeninas y sumisas).

39 FAur y Medan (2010).

40 Faur y Medan (2010), p. 57.

41 SAntoro (2007).

42 Santoro (2007).

43 González y Paredes (2004).

44 Véase Furham y Mak (1999) (quienes realizaron un estudio sobre el rol de los estereotipos de género en los comerciales televisivos comparando y contrastando 14 estudios realizados en cinco continentes, particularmente en los siguientes países: Estados Unidos, Australia, Dinamarca, Francia, Reino Unido, Hong Kong, Indonesia, Italia, Kenya, México y Portugal). Para estudios 
generalmente representada como emocional, sexual y atractiva, orientada al espacio privado, dependiente, sacrificada, deseosa de agradar, maternal, familiar, emotiva y sentimental. En cambio, el varón adulto es mayormente representado como racional, enérgico y agresivo, centrado en sí mismo, orientado hacia el espacio público, decidido e independiente, seguro de sí mismo, señorial y dominante. ${ }^{45}$ Por su parte, las niñas son representadas como tímidas, pasivas, débiles, cariñosas y emotivas; juegan a cocinar, a planchar y a cuidar niños; les gustan las muñecas, los vestidos y el color rosa. ${ }^{46} \mathrm{~A}$ los niños, en cambio, se los muestra como autónomos, enérgicos y agresivos, dominantes, creativos; juegan al fútbol, el rugby y los deportes extremos; les gustan los autos, los trenes, los aviones y el color celeste. ${ }^{47}$ Un ejemplo elocuente de cómo la publicidad orienta a partir de estereotipos el gusto de los consumidores infantiles es la publicidad de huevos de chocolate Kinder que se efectuó en Argentina con envases diferenciados por género (rosa para niñas y celeste para niños), lo cual anticipaba qué tipo de juguete tendrían adentro (si era celeste, un autito o un jugador de fútbol; si era rosa, muñecas o flores). Todo ello da cuenta de cómo la publicidad influye en la construcción de los estereotipos de género y de cuál es su rol en la transmisión y permanencia de mandatos y expectativas sociales diferenciados por género.

Otros estudios, más focalizados en mostrar el impacto de la publicidad estereotipada que va dirigida a nuestro subconsciente, se preocupan por descifrar la potencial correlación entre los estereotipos de género representados y reforzados en la publicidad y los posibles efectos adversos para las mujeres (aunque no exclusivamente para ellas). ${ }^{48}$ Veamos algunos ejemplos: (i) revelan que las publicidades que muestran modelos ideales de cuerpos femeninos inalcanzables representan una de las causas

realizados recientemente en Argentina, véase RAMírez BARAHONA (2018), p. 31 (mostrando, entre otros aspectos, que en el $91 \%$ de los anuncios se muestra a mujeres jóvenes; el $41 \%$ ubica a la mujer en espacios domésticos; en un 70\% la mujer se caracteriza por aspectos emocionales como el amor, la imaginación y la felicidad).

45 Véase Melo y Astorino (2016), pp. 38-39 (quienes muestran ejemplos en Argentina de publicidades como la de Hipoglós en las cuales se ridiculiza el rol del hombre "amo de casa" como una forma de expresar lo poco habitual de esas actividades o espacios para el padre/varón).

46 En una línea similar, el Consejo Asesor de la Comunicación Audiovisual y la Infancia del Gobierno Argentino ha advertido que, en las publicidades de juguetes, los automóviles o los muñecos de superhéroes se dirigen exclusivamente a los varones y utilizan locuciones masculinas y una edición vertiginosa en la que se destacan la acción, los sonidos de motores, los golpes y las explosiones, acompañados de colores fuertes como rojos o azules. Mientras que a las niñas se les ofrecen diversos tipos de muñecos de colección -series de princesas, sellos de distintos colores y perfumes, muñecos de peluche- en spots en los que predominan la locución femenina y jingles melódicos de voces suaves, así como los colores pasteles.

47 Véase Melo y Astorino (2016), p. 18 (evidenciando que "las publicidades de productos infantiles constituyen una instancia más de violencia simbólica hacia las mujeres, ya que se perpetúan una serie de modelos de 'ser mujer' asociados a los quehaceres domésticos/privados, a la sumisión, a los roles pasivos en la sociedad, entre otros, y en oposición a modelos de 'ser varón' anclados a roles activos, de fuerza, superioridad, actividades públicas, etc.”).

48 Véase Femenías (2013), pp. 102-103 (argumentando que "las apelaciones históricas a las mujeres en términos de: inmadura, emocional, frígida, fregona, diosa, frívola, inconsciente, vulnerable, incapaz, quejosa, loca, etc., han tenido eficacia apelativa y performativa [sobre todo] si los discursos sociales lo ratifican"). 
de enfermedades como la bulimia y la anorexia en mujeres adolescentes y, al mismo tiempo, contribuyen a generar distorsiones en la manera en que las mujeres se ven a sí mismas y cómo el resto las percibe, lo que genera problemas de baja autoestima e inseguridad por no poder alcanzar los ideales de belleza y juventud implantados, y restringe sus potenciales elecciones de vida; ${ }^{49}$ (ii) establecen correlaciones entre publicidades sexistas que repetidamente objetivizan y banalizan a la mujer con situaciones de acoso sexual en el trabajo, acoso callejero y violencia física y simbólica dirigida hacia mujeres adultas y adolescentes $;^{50}$ (iii) muestran cómo las publicidades que representan a las mujeres a cargo de las tareas del hogar y del cuidado de los hijos se relacionan con un mensaje que las excluye de ciertas actividades que se representan como predominantemente masculinas (p. ej., jugar al fútbol, ejercer posiciones ejecutivas y de toma de decisión, etc.), lo cual afecta las aspiraciones y las expectativas de las mujeres en el mundo del trabajo y en la sociedad en general (p. ej., conformarse con trabajos administrativos y burocráticos, ocupar un rol secundario a la hora de expresar opiniones o posturas en reuniones de trabajo, etc.) $)^{51}$ y (iv) muestran cómo los mensajes publicitarios estereotipados dirigidos a niños y niñas refuerzan la desigualdad entre varones y mujeres al influir en su proceso de socialización (aprendizaje mediante el cual incorporan los valores y las costumbres de la sociedad en la que viven con el fin de adaptarse a su ambiente, al diferenciar lo aceptable y lo inaceptable de su comportamiento), lo que afecta desde muy temprana edad su manera de ver el mundo, de relacionarse con los otros y de construir una opinión sobre sí mismos. ${ }^{52}$

En esta línea, la Convención sobre la eliminación de todas las formas de discriminación contra la mujer (CEDAW) ha reconocido el impacto de los estereotipos de género como un impedimento para la igualdad de género y el empoderamiento de las mujeres en sociedad. ${ }^{53}$ Asimismo, una gran variedad de estudios empíricos a

49 Véase Monge-Rojas et al. (2015) (mostrando la correlación entre los estereotipos de género y los hábitos alimentarios no saludables de las adolescentes que las conduce en muchos casos a enfermedades como bulimia y anorexia en Costa Rica).

50 Véase Arias (2015) y Alonso (2015) (mostrando la íntima vinculación entre los estereotipos femeninos reproducidos y reforzados por los medios de comunicación y la violencia contra las mujeres en Argentina).

51 Véase, p. ej., Suárez Villegas (2013), p. 247 (argumentando que "la maternidad viene con frecuencia encumbrada como el modelo de vida más auténtico de las mujeres y, con frecuencia, como el único. A esta consolidación del imaginario femenino como la cuidadora permanente de la descendencia familiar contribuyen de manera decisiva los discursos publicitarios, pues son ellas las que aparecen de manera exclusiva en los distintos escenarios relacionados con su crianza y cuidado"). Un reciente estudio realizado por Unilever en China, India e Indonesia reveló que solo el $2 \%$ de las publicidades muestran a las mujeres en roles aspiracionales y de liderazgo, véase más en https://www.scmp.com/lifestyle/health-wellness/article/2168711/how-gender-stereotypingadverts-bad-women-and-men-and-why. Para un análisis de la relación entre estereotipos de género y su influencia en los problemas que enfrentan las mujeres en posiciones de liderazgo, véase GARCía Beaudoux (2015).

52 Véase Melo y Astorino (2016), y Colín (2017) (quien trabaja la problemática de la ausencia de perspectiva de género en los programas escolares en México).

53 Véase CEDAW de 1979: "Los Estados Partes tomarán todas las medidas apropiadas para: a) Modificar los patrones socioculturales de conducta de hombres y mujeres, con miras a alcanzar 
nivel global evidencian que la publicidad estereotipada es un instrumento eficaz para la cristalización y la naturalización de la desigualdad de género y como expresión de violencia mediática hacia las mujeres. ${ }^{54}$

Debido a nuestros sesgos cognitivos en la toma de decisiones (particularmente status quo y arrastre) y a la influencia del contexto social en el que decidimos, la injerencia de la publicidad estereotipada en nuestra sociedad es mayor y más grave de lo que tendemos a considerar. Es importante desmitificar la idea generalizada de que el impacto de la publicidad es mayormente la decisión efectiva del consumidor de comprar un producto o un servicio determinado (que en muchos casos no necesita). A decir verdad, la publicidad produce un por lo común inadvertido impacto subliminal: al tiempo que reproduce, naturaliza y afianza expectativas sobre lo femenino y lo masculino en clave binaria y dicotómica, cancela e invisibiliza a otros actores, otros planes de vida y otras posibilidades de pensar o dar cuenta de la realidad por fuera de aquel modelo heteronormativo. Dicho impacto subliminal de la publicidad, que excede el acto de consumo en sí mismo, se manifiesta concretamente en la afectación a la autoestima, la confianza personal y la proyección de oportunidades y de planes de vida de las personas, lo que disminuye su bienestar general y afecta su autonomía individual..$^{55}$

\section{RESPUESTAS DEL DEREGHO: EL GASO ARGENTINO}

Una vez comprendidas las dinámicas de comportamiento de los actores relevantes del mercado, la importancia del contexto social y cultural en el que el fenómeno publicitario se desarrolla y la dimensión de su impacto en los receptores, nos encontramos en mejores condiciones para analizar la regulación de la publicidad. ${ }^{56}$

la eliminación de los prejuicios y las prácticas consuetudinarias y de cualquier otra índole que estén basados en la idea de la inferioridad o superioridad de cualquiera de los sexos o en funciones estereotipadas de hombres y mujeres [...]" (Art. 5); y "Los Estados Partes adoptarán todas las medidas apropiadas para eliminar la discriminación contra la mujer, a fin de asegurarle la igualdad de derechos con el hombre en la esfera de la educación y en particular para asegurar, en condiciones de igualdad entre hombres y mujeres: [...] c) La eliminación de todo concepto estereotipado de los papeles masculino y femenino en todos los niveles y en todas las formas de enseñanza, mediante el estímulo de la educación mixta y de otros tipos de educación que contribuyan a lograr este objetivo y, en particular, mediante la modificación de los libros y programas escolares y la adaptación de los métodos en enseñanza [...]" (Art. 10).

54 Véase, p. ej., Melo y Astorino (2016), y Hernández y Fernández de la Vega (2016). Para una definición de "violencia mediática", véase, p. ej., el texto de la Ley No 26.485 de 2009 (Argentina). "Violencia mediática contra las mujeres: aquella publicación o difusión de mensajes e imágenes estereotipados a través de cualquier medio masivo de comunicación, que de manera directa o indirecta promueva la explotación de mujeres o sus imágenes, injurie, difame, discrimine, deshonre, humille o atente contra la dignidad de las mujeres, como así también la utilización de mujeres, adolescentes y niñas en mensajes e imágenes pornográficas, legitimando la desigualdad de trato o construya patrones socioculturales reproductores de la desigualdad o generadores de violencia contra las mujeres" (Art. 6 inc. f).

55 La idea es que para tomar decisiones autónomas necesitamos un contexto social que nos facilite hacerlo al ofrecer diversidad de opciones alternativas y posibilidades.

56 En el derecho argentino, por ejemplo, se define a la publicidad en la Ley $N^{\circ} 26.522$ de 2009: "Toda forma de mensaje que se emite en un servicio de comunicación audiovisual a cambio de 
Ciertamente, a la hora de regular la publicidad y establecer las reglas de juego para sus creadores, hay varias cuestiones en pugna. Lo que es claro es que ante el innegable desequilibrio en la relación consumidor-proveedor profesional, el derecho debe intervenir para resolver esa situación que genera inequidad, con medidas activas que doten al consumidor de conocimiento y herramientas protectorias. ${ }^{57}$ Tiene sentido que esta respuesta se busque en el derecho y no en el proveedor profesional de bienes y servicios, ya que este último tiene problemas de acción colectiva que vuelven poco probable que tome esta iniciativa..$^{58}$

Sin embargo, el derecho no ha sido sensible al corrimiento de la línea entre informar y persuadir en la misma medida en que este fenómeno se ha ido manifestando en el contexto de las modernas dinámicas de mercado. La regulación de la publicidad ha sido en su gran mayoría abordada por el derecho desde su aspecto informativo, y se ha relegado a un segundo plano la necesidad de brindar herramientas de protección al consumidor frente a su faz persuasiva. ${ }^{59}$ Así, la mayoría de las legislaciones prohíben la publicidad engañosa ${ }^{60}$ y la desleal, ${ }^{61}$ que apuntan principalmente a proteger al consumidor frente a indicaciones falsas o comparaciones de bienes y servicios que lo induzcan o puedan inducir a error sobre elementos esenciales del producto o servicio. ${ }^{62}$

una remuneración o contraprestación similar, o bien con fines de autopromoción, por parte de una empresa pública o privada o de una persona física en relación con una actividad comercial, industrial, artesanal o profesional con objeto de promocionar, a cambio de una remuneración, el suministro de bienes o prestación de servicios, incluidos bienes, inmuebles, derechos y obligaciones" (Art. 4).

57 Wajntraub (2017), Stiglitz y Hernández (2015).

58 BAR-GILL (2014).

59 Véase, p. ej., la regulación del deber de información de la Ley Nº 26.994 de 2014 (Argentina). "El proveedor está obligado a suministrar información al consumidor en forma cierta y detallada, respecto de todo lo relacionado con las características esenciales de los bienes y servicios que provee, las condiciones de su comercialización y toda otra circunstancia relevante para el contrato. La información debe ser siempre gratuita para el consumidor y proporcionada con la claridad necesaria que permita su comprensión" (Art. 1100); y de la Ley No 24.240 de 1993 (Argentina). "Información. El proveedor está obligado a suministrar al consumidor en forma cierta, clara y detallada todo lo relacionado con las características esenciales de los bienes y servicios que provee, y las condiciones de su comercialización" (Art. 4).

60 Véase, p. ej., la regulación de la "publicidad engañosa” de la Ley № 26.994 de 2014 (Argentina). "Está prohibida toda publicidad que contenga indicaciones falsas o de tal naturaleza que induzcan o puedan inducir a error al consumidor, cuando recaigan sobre elementos esenciales del producto o servicio" (Art. 1101 inc. a).

61 Véase, p. ej., la regulación de la "publicidad desleal” de la Ley No 26.994 de 2014 (Argentina). "Está prohibida toda publicidad que efectúe comparaciones de bienes o servicios cuando sean de naturaleza tal que conduzcan a error al consumidor" (Art. 1101 inc. b).

62 Véase IbáÑez (2019), p. 360 (argumentando que lo que la ley persigue "es evitar que la publicidad ocasione precisamente desinformación o confusión, es decir, engaño”), y BAROcELLI (2016) (argumentando que a la hora de determinar la aptitud de engaño o inducción a error de la publicidad debe tenerse en cuenta la situación de hipervulnerabilidad estructural de los consumidores en el mercado). 
Esta regulación clásica de la publicidad como información presenta al menos dos problemas con incidencia práctica importante: (i) encorseta el análisis de la publicidad prohibida bajo un test objetivo de verdad/falsedad que no permite capturar el elemento persuasivo, el cual justamente se caracteriza por estar en un límite difuso entre lo falso y lo verdadero y, la mayoría de las veces, incluso, por fuera de esas categorías; ${ }^{63}$ y (ii) asume que el impacto de la publicidad en el consumidor se reduce exclusivamente al mero acto de adquirir un producto o servicio determinado, sin tener en cuenta el significado del acto de consumo o el impacto subliminal que la publicidad produce en el receptor y en la sociedad o colectivo de consumidores en general referido en el apartado anterior.

Una razón por la cual el derecho no se ha preocupado demasiado por regular la faz persuasiva de la publicidad podría ser que la "persuasión" entendida en términos amplios como "hacer cambiar a alguien de opinión" resuena como aceptable, mientras que engañar o forzar a alguien a hacer algo claramente no lo es. ${ }^{64}$ La idea subyacente a esto parece ser que el derecho puede exigirle veracidad al proveedor profesional aunque no imparcialidad. ${ }^{65}$ Sin embargo, identificar el real funcionamiento de la faz persuasiva de la publicidad y la dimensión de su impacto en nuestra sociedad nos impone un cambio de actitud: debería importarnos y es algo respecto de lo cual el derecho debería empezar a ofrecer soluciones más concretas, en lugar de ampararse en la posible afectación en abstracto a la "libertad de expresión" del creador que generaría, por ejemplo, la prohibición de ese tipo de publicidad, clásico argumento utilizado para no regularla. ${ }^{66}$ Lo cierto es que el derecho a la libertad de expresión

63 Véase KuenzLer (2019), p. 265 (argumentando que la cuestión que el derecho enfrenta es la de captar aquellos supuestos en los cuales la publicidad "presenta información que no es ni completamente falsa o engañosa ni enteramente incorrecta".

64 Véase Santarelui (2016), p. 710 (expresando que "es lícito que la publicidad se desinterese por informar y se remita a otro tipo de mensaje; en tanto persiga atraer, sugerir, motivar, el consumo de un objeto, de una marca, etc. Aun en estos casos, la publicidad no puede atentar contra el principio de transparencia, es decir inducir a confusión o a error respecto de los elementos del producto o sus formas de comercialización"); y PASQUAU Liaño (1992), p. 143 (argumentando que "la publicidad podrá ser lícitamente parcial, persuasiva, incitadora, incluso -en cierto modo- manipuladora, pero en todo caso ha de ser veraz (...) por debajo del límite de la veracidad, se entra en el campo de lo ilícito, y de la mediación jurídica"). Para un análisis de la diferencia entre persuasión, coerción y manipulación, véase Susser et al. (2018).

65 Véase Acciarri y Tolosa (2009), pp. 20-21 (argumentando que "[s]i bien la publicidad es un medio muy valioso para transmitir información a los consumidores, no resulta estrictamente equivalente a información veraz, y menos completa. De modo característico la publicidad tiende a ocultar aspectos desfavorables del producto y a exacerbar ciertas cualidades positivas, y en ningún caso es imparcial o de veracidad verificada").

66 Para un análisis de la relación entre publicidad abusiva y libertad de expresión, véase PerAL (2019), pp. 216-220, y LORENZETTI (2009), pp. 182-183 (argumentando que la finalidad comercial del mensaje publicitario hace que la protección de la libertad de expresión sea mucho más tenue). Véase TAmbussi (2015), p. 773 (quien argumenta que la publicidad subliminal debe prohibirse por la legislación porque se caracteriza "por ingresar al consumidor por medio de la manipulación psicológica, por ser imperceptible al consciente de quien recibe el mensaje, afectando de manera violenta la libertad de elección, la intimidad y la dignidad, viciando el consentimiento y afectando 
del proveedor no es absoluto y deberá, por lo tanto, balancearse con el derecho a la información y a un trato equitativo y digno de los consumidores y usuarios, ambos derechos de igual jerarquía constitucional. ${ }^{67}$

Recientemente, algunas legislaciones de América Latina han mostrado avances en dicho sentido al incluir la regulación de la publicidad abusiva, dirigida a prohibir toda publicidad que sea "abusiva, discriminatoria o induzca al consumidor a comportarse de manera perjudicial o peligrosa para su salud o seguridad". ${ }^{68}$ Como se puede advertir, la regulación de la publicidad abusiva da un cierto espacio para romper con el estricto corset del binomio verdad/falsedad y comenzar a captar algunos de los aspectos persuasivos de la publicidad y su posible impacto en el receptor, que excede el acto de consumir per se.

El reciente Anteproyecto de Reforma de la Ley de Defensa del Consumidor de Argentina (2018) propone avanzar aún más en dicho sentido ampliando la categoría de publicidad abusiva a aquellas que "atenten contra el derecho fundamental a la salud de los niños, niñas y adolescentes, la identidad de género y las que afecten de cualquier modo los bienes ambientales o culturales" ${ }^{69}$ Esta regulación de la publicidad abusiva se complementa a su vez con la propuesta de regulación de las prácticas abusivas, entendiendo como tales a aquellas conductas "que de modo directo o indirecto estereotipen, promuevan o estimulen patrones socioculturales sustentados sobre la desigualdad de género y las relaciones de poder sobre las mujeres" ${ }^{70}$ En este sentido, incurre en práctica abusiva el proveedor que para publicitar sus productos o servicios realice publicidades estereotipadas. ${ }^{71}$

la buena fe. Por la forma en que el mensaje ingresa o llega, el consumidor no tiene posibilidad de repeler el ataque, porque no lo detecta").

67 Véase Constitución de la Nación Argentina, Art. 42 y los Tratados Internacionales de Derechos Humanos con jerarquía constitucional conforme al Art. 75 inc. 22

68 Véase Ley N² 26.994 de 2014, Art. 1101 inc. c) (Argentina). En un sentido similar, véase Ley Nº 8.078 de 1990 (Brasil). publicidad abusiva es "la publicidad discriminatoria de cualquier naturaleza, la que incite la violencia, explote el miedo o la superstición, se aproveche de la deficiencia de juzgamiento y de la inexperiencia de los niños, vulnere los valores ambientales, o que sea capaz de inducir al consumidor a comportarse de manera perjudicial o peligrosa para su salud o seguridad" (Art. 37.2). Véase también Ley N²6.522 de 2009 (Argentina). "No se emitirá publicidad subliminal entendida por tal la que posee aptitud para producir estímulos inconscientes presentados debajo del umbral sensorial absoluto" (Art. 81 f).

69 Véase Anteproyecto de Ley de Defensa del Consumidor de 2018: Art. 45 (Argentina). En una línea similar, véase Ley No 26.522 de 2009 (Argentina). "Los avisos publicitarios no importarán discriminaciones de raza, etnia, género, orientación sexual, ideológicos, socio-económicos o nacionalidad, entre otros; no menoscabarán la dignidad humana, no ofenderán convicciones morales o religiosas, no inducirán a comportamientos perjudiciales para el ambiente o la salud física y moral de los niños, niñas y adolescentes" (Art. 81 i).

70 Véase Anteproyecto de Ley de Defensa del Consumidor de 2018: Art. 26. Inc. $2^{\circ}$ (Argentina).

71 Véase Arias y Trivisonno (2019), p. 308, y Chamatropulos (2019), Vol. 1, p. 443 (argumentando que serán consideradas publicidades abusivas los anuncios que fomenten o inciten a profundizar desigualdades estructurales de género). 
Las conductas descriptas en ambas proyecciones normativas se articulan con la Ley Nacional de Protección Integral de las Mujeres (Argentina) que se encuentra en clave constitucional, y garantiza y reglamenta los derechos reconocidos por la Convención para la eliminación de todas las formas de discriminación contra la mujer (CEDAW) y la Convención interamericana para prevenir, sancionar y erradicar la violencia contra la mujer. En esa línea, la regulación que prohíbe la publicidad estereotipada en el ámbito del consumo es una manifestación de la obligación del Estado argentino de adoptar medidas de acción positiva para garantizar la igualdad y erradicar los estereotipos de género en nuestra sociedad, al tiempo que constituye una limitación razonable al ejercicio de la libertad de expresión del proveedor. ${ }^{72}$

Esta novedosa propuesta de ampliación del ámbito de regulación de la publicidad abusiva y su articulación con la identificación de las prácticas abusivas busca captar el impacto subliminal que la misma produce en niños, niñas, adolescentes y personas adultas y dar de algún modo una respuesta. Respecto al contenido de la publicidad estereotipada, si bien no identifica concretamente qué estereotipos de género se prohíben, como sí lo hacen en cambio recientes reformas legislativas que han tenido lugar en el Reino Unido, ${ }^{73}$ en Francia ${ }^{74}$ y en Australia, ${ }^{75}$ y otras iniciativas globales ${ }^{76}$ lo aborda de una manera que entiendo es más inclusiva al prohibir toda publicidad que atente contra la identidad de género y que estereotipe, promueva o estimule patrones socioculturales sustentados sobre la desigualdad de género y las relaciones de poder sobre las mujeres.

72 Arias y Trivisonno (2019), p. 309. En similar sentido, véase Peral (2019), p. 220 (entendiendo como ilícita a la publicidad estereotipada).

73 Véase SAFronova (2019) (quien menciona ejemplos de publicidades estereotipadas que están prohibidas en el Reino Unido a partir de 2019, a saber: hombres incapaces de cambiar pañales, mujeres que limpian mientras los hombres están sentados en un sillón descansando, mujeres que tienen problemas para estacionar el auto, publicidades que conectan apariencia física con éxito en el amor o en esferas sociales, que asignan personalidades estereotipadas a niños y niñas, como por ejemplo valentía para los niños y ternura para las niñas, publicidades que sugieren que las madres deben priorizar su apariencia física y limpieza del hogar por sobre su salud emocional, publicidades que ridiculizan al hombre por ser malo al realizar actividades esterotípicamente femeninas, como aspirar, lavar la ropa o cuidar de la familia, entre otros). En una línea similar, menciona que países como Bélgica, Francia, Finlandia, Grecia, Sudáfrica e India tienen alguna ley o código, con variaciones, que prohíben la discriminación por género en la publicidad. Noruega, por ejemplo, tiene una ley que prohíbe sexismo en la publicidad desde 1978. En cambio, en Estados Unidos, el foco es más bien la publicidad estereotipada dirigida al público infantil.

74 En Francia, desde 2017, las publicidades que usen imágenes de cuerpos digitalmente alteradas sin introducir una advertencia al respecto podrán ser sancionadas con una multa de €37,500 o hasta el 30\% del costo de producción de la publicidad, véase más en https://www.independent.co.uk/ life-style/fashion/photoshop-models-france-ban-2017-october-a7975351.html.

75 En Australia se dictaron recientes leyes que prohíben la publicidad que refuerce o promueva estereotipos negativos de género; que cosifique o represente a la mujer como un objeto sexual, y que promuevan ideales de cuerpos insalubres.

76 Por ejemplo, globaldemocracy.org promueve la exigencia de indicación expresa del publicista de que los cuerpos que figuran en las fotos han sido manipulados con Photoshop. 
Para clarificar, ambas propuestas de regulación de los estereotipos de género en la publicidad son valiosas ya que de algún modo dan cuenta del impacto subliminal del aspecto persuasivo del fenómeno publicitario. Sin embargo, entiendo que la regulación que apunta a prohibir la promoción de la "desigualdad de género" y la afectación a la "identidad de género" es quizás más sensible a la raíz del problema: la publicidad debería representar la diversidad propia de nuestro contexto social y cultural. Es decir, debemos no solo preocuparnos por erradicar los estereotipos negativos femeninos y masculinos que están arraigados en la publicidad, sino también ocuparnos de generar contenidos de publicidad que reflejen la diversidad de la sociedad en la que vivimos de una manera que incluya y haga visibles otros planes de vida, y otras posibilidades de pensar o dar cuenta de la realidad por fuera del binomio heteronormativo (p. ej., publicidades que representen a personas del colectivo LGBT, diversidad de modelos de familia, diversidad de cuerpos femeninos, etc.). ${ }^{77}$

Es decir, si bien la regulación que prohíbe determinados contenidos estereotipados (p. ej., que cosifique o represente a la mujer como objeto sexual o que promueva ideales de cuerpos insalubres, entre otras) es ciertamente valiosa y significa un avance muy importante para dar respuestas desde el derecho al problema de la publicidad estereotipada, por sí sola no es suficiente para atacar la raíz de la cuestión. El desafío es lograr que el creador de publicidad piense las representaciones mediáticas por fuera del modelo heteronormativo e incorpore también las diversidades familiares, las orientaciones sexuales y las identidades de género a la reflexión, lo que permitiría mayor pluralidad. ${ }^{78}$ La publicidad debe representar todas las alternativas que están presentes en la sociedad como una especie de espejo con el que cada uno de los miembros de la comunidad pueda sentirse identificado, para mostrar así un compromiso con una sociedad más igualitaria. ${ }^{79} \mathrm{~A}$ pesar de la existencia en Argentina de un rico marco normativo que brinda algunas (aunque limitadas) herramientas jurídicas de protección,$^{80}$ los medios de comunicación han mostrado avances muy

77 Por ejemplo, recientemente, Nike introdujo en su local de Londres maniquíes de todas las formas y tallas que representan diferentes tipos de cuerpos de mujeres deportistas. Otro ejemplo son las revistas Elle, Cosmopolitan y Vogue que han elegido recientemente modelos plus size o de "talla grande" para sus portadas.

78 Para iniciativas en este sentido en Argentina, las cuales complementan la normativa existente, véase el Protocolo de Actuación Publicitaria no Sexista y Diversa de 2018 que tiene por objeto "promover la transformación del discurso publicitario (en Argentina) desde un enfoque de comunicación no sexista y diversa" y propone, como principios rectores, entre otros, los siguientes: "Promover caracterizaciones y/o representaciones de personajes que muestren diversidad en las formas de ser mujer, en las figuras físicas y en los estilos de vida [...] Representar a los varones en la diversidad de masculinidades (gays, varones trans) y evitar construir exclusivamente caracterizaciones desde la masculinidad heterosexual hegemónica, mostrándolos como personas que no deben expresar afecto o emociones y que siempre deben estar dispuestos al intercambio sexual".

79 Por ejemplo, el Protocolo de Actuación Publicitaria no Sexista y Diversa de 2018 indica que, en Argentina, se registran solo unos pocos casos de participación de personas trans en anuncios publicitarios, lo que conforma una práctica en sí discriminatoria porque las invisibiliza.

80 Las principales normativas vigentes en Argentina en materia de género y publicidad: Ley N 26.485 de 2009, Ley No 26.522 de 2009, Ley No 26.743 de 2012. 
tímidos en dicho sentido. ${ }^{81}$ Estudios empíricos realizados en Argentina en los últimos años dan cuenta de un movimiento importante en la remoción de los estereotipos de género por parte del Estado, ${ }^{82}$ de la sociedad ${ }^{83}$ y de las organizaciones sociales, ${ }^{84}$ al tiempo que denuncian la falta de compromiso de los creadores de publicidad con la superación de los estereotipos de género. ${ }^{85}$ Estos, salvo aisladas excepciones ${ }^{86}$ se esfuerzan más bien por mantener el status quo y no aggiornar los contenidos publicitarios para alinearlos con los cambios normativos y las políticas públicas con perspectivas

81 Véase Melo y Astorino (2016), p. 22

82 En Argentina, algunas experiencias en monitoreo de publicidad por estereotipos de género puede verse en el trabajo realizado por la Defensoría del Público de Servicios de Comunicación Audiovisual. Véase más en: http://defensadelpublico.gob.ar/lineas-de-accion/publicidad/. Como ejemplos, lo trabajado en la publicidad de la compañía de cerveza Andes con la campaña "Huracanes". Luego de las gestiones realizadas por el organismo, la empresa decidió retirar del aire la campaña publicitaria, en: http://defensadelpublico.gob.ar/casos-resueltos/huracanes-de-la-cerveza-andes/. Igualmente, lo conversado con TyCSports por su campaña "Putín", para el Mundial de Rusia 2018, en: http://defensadelpublico.gob.ar/reunion-con-tyc-sports-y-la-agencia-publicitaria-mercado-mccann/. Así también, los casos de la publicidad de Asepxia y problemas en la piel y estereotipos, en: http://defensadelpublico.gob.ar/luego-de-las-denuncias-el-compromiso-de-cambiar-la-publicidad/ http://archivo.defensadelpublico.gob.ar/es/resolucion-no-129-2013. Por su parte, el Observatorio para la Discriminación en Radio y Televisión sobre Discriminación de las Mujeres en los Medios de Comunicación Audiovisual (INADI, Argentina) se encarga de identificar publicidades sexistas, las analiza y aplica las correspondientes sanciones.

83 Véase infra nota 91.

84 Por ejemplo, la Asociación Civil Comunicación para la Igualdad, la Fundación para el Desarrollo de Políticas Sustentables (FUNDEPS), Publicitarias.org, entre muchas otras.

85 Véase Ramírez Barahona (2018), p. 35 (señalando que "desde el punto de vista del ámbito empresarial los esfuerzos por erradicar estereotipos sexistas no aparecen como un interés común de la industria publicitaria [Argentina], sino que se circunscriben a acciones aisladas y esporádicas").

86 En Argentina, algunas empresas, de modo excepcional y por iniciativa propia, comenzaron a incorporar en sus campañas caracterizaciones más inclusivas y diversas de las distintas formas de ser y estilos de vida de mujeres y varones. Por ejemplo, la marca de limpiadores Mr. Músculo, tradicionalmente posicionada a través de un personaje masculino caracterizado como un superhéroe que brinda soluciones de limpieza a las mujeres, produjo en 2016 una publicidad en el que el varón aparece a cargo de las tareas de limpieza del hogar y del cuidado de su pequeña hija, además de mantener un trabajo. Históricamente, esta marca asignó a las mujeres casi de manera exclusiva la responsabilidad por las tareas de cuidado y limpieza que componen la doble jornada laboral, formal y doméstica. De modo que aquí se registra un cambio en la mirada y un posicionamiento novedoso en esta línea de productos. En el mismo año, una empresa de productos de blanco para el hogar, Arredo, promovió una campaña para redes sociales en la que incluyó parejas del mismo sexo compartiendo la cama. Por su parte, el agua saborizada We de la marca Ser produjo un comercial titulado "La vida es una mezcla maravillosa", que mediante animación digital muestra a dos mujeres besándose mientras la locución menciona expresamente el "matrimonio igualitario". Levité, una marca de la competencia en el rubro de aguas saborizadas produjo el comercial llamado "Liberate", con locución a cargo de Lizy Tagliani, una reconocida actriz y comediante transgénero. Véase más ejemplos en Comunicación para la Igualdad http://www.comunicarigualdad.com.ar. 
de género, ${ }^{87}$ y los procesos culturales y sociales ${ }^{88}$ experimentados por la sociedad argentina en los últimos años. Es decir, en general, los creadores de publicidad en Argentina continúan contribuyendo a la reproducción de estereotipos de género que son de algún modo obsoletos. ${ }^{89}$

Por supuesto, la prohibición de la publicidad estereotipada es una de las posibles herramientas que puede brindar el derecho aunque no necesariamente la única; por ejemplo, sanciones administrativas de contrapublicidad pueden funcionar quizás como un efectivo complemento. ${ }^{90}$ Pensar que prohibir la publicidad que represente "estereotipos negativos de género" o atente contra la "identidad de género" o la "igualdad de género" será la solución al problema es ciertamente utópico. En un contexto en el que el derecho mismo ha facilitado de alguna manera la perpetuación de prácticas publicitarias estereotipadas, se advierte que su rol es limitado para brindar por sí mismo respuestas efectivas si las mismas no van acompañadas de otro conjunto de cambios estructurales en las dinámicas de actuación de los actores involucrados. A la par de dicha regulación (y quizás de otras herramientas jurídicas complementarias), hay que lograr la capacitación y la colaboración de los productores de publicidad, que son quienes tienen una gran capacidad para promover un cambio social. Se deberá trabajar en lograr un cambio

87 Ejemplos de leyes dictadas y organismos del Estado creados en los últimos años en Argentina que se relacionan con la temática de género: Ley No 26.485 de 2009, Ley $N^{\circ} 26.522$ de 2009, Ley $N^{\circ} 26.743$ de 2012, Ley № 26.618 de 2010, conocida como "Ley de matrimonio igualitario", Observatorio de la Discriminación en Radio y Televisión (iniciado en 2006 bajo la órbita del ex Comité Federal de Radiodifusión), la ex Autoridad Federal de Servicios de Comunicación Audiovisual creada por la LSCA (2009-2015, actual Ente Nacional de Comunicaciones), la Defensoría del Público de Servicios de Comunicación Audiovisual creada por la misma ley y que inició su actividad en 2012 y la Oficina de Monitoreo de Anuncios de Oferta Sexual (2011), Ley No 27.499 de 2018, conocida como "Ley Micaela" (establece la capacitación obligatoria en la temática de género y violencia contra las mujeres para todas las personas que se desempeñen en la función pública en todos sus niveles y jerarquías en los Poderes Ejecutivo, Legislativo y Judicial de la República Argentina). Esta enumeración no es exhaustiva ya que existen en Argentina otras normas e instancias oficiales que trabajan los diversos aspectos relacionados al género, el sexismo y la violencia contra las mujeres. Para conocer en detalle las leyes y los espacios gubernamentales que comenzaron a abordar con especial dedicación la problemática de género y las comunicaciones, se recomienda ver CHAHER y PedRAZa (2018).

88 Por ejemplo, en 2015, el Ni Una Menos revolucionó los compartimientos estancos de la sociedad patriarcal argentina.

89 Véase Putruele (2019) (describiendo que el 76\% de las consumidoras mujeres y el 71\% de los hombres cree que la publicidad los representa de manera completamente desactualizada).

90 Véase, p. ej., Anteproyecto de Ley de Defensa del Consumidor de 2018 (Argentina) donde se propone introducir como medida complementaria la sanción administrativa de contrapublicidad: "Contrapublicidad. Sin perjuicio de [...] la orden de cesación de los anuncios o mensajes, se podrá imponer la sanción administrativa de contrapublicidad, al infractor que, a través de la información o publicidad, hubiera incurrido en prácticas engañosas o abusivas. Asimismo, la Autoridad de Aplicación podrá publicar a costa del infractor, conforme el criterio por esta indicado, la resolución condenatoria o una síntesis de los hechos que la originaron, el tipo de infracción cometida y la sanción aplicada, en un diario de gran circulación, que deberá ser elegido de modo rotativo. La reglamentación establecerá las pautas de la rectificación publicitaria de forma capaz de eliminar los efectos de la infracción, y que será divulgada por la Autoridad de Aplicación o el responsable, a costa de este último, en la misma forma, frecuencia y dimensión, y preferentemente por el mismo medio, lugar, espacio y horario" (Art. 158). 
cultural profundo. Es importante adoptar medidas estructurales que promuevan un discurso publicitario inclusivo y diverso que asegure, por ejemplo, la participación equitativa de mujeres y otros géneros en todas las áreas de trabajo, y especialmente en puestos de toma de decisión dentro de las empresas y agencias de publicidad, ${ }^{91}$ e introduzca los contenidos de género de forma transversal en los programas educativos y, en particular, en las escuelas de publicidad y comunicación, entre otras medidas. ${ }^{92}$ Por otro lado, hay respuestas que provienen desde la sociedad misma: en el contexto de las nuevas tecnologías no podemos soslayar el rol amplificador que cumplen las redes sociales como canales de expresión de las voces de los consumidores y como mecanismos informales para ejercer como ciudadanos algún control sobre los contenidos estereotipados de la publicidad. ${ }^{93}$

\section{GONGLUSIÓN}

La publicidad es información que tiene por objetivo persuadir. El fenómeno publicitario conecta al proveedor profesional (creador) y al consumidor (receptor) bajo las dinámicas propias del mercado y en el marco de un contexto social y cultural determinado. Entender a la publicidad como una herramienta aislada del contexto y eminentemente informativa no solo invisibiliza su faz persuasiva sino que representa un obstáculo para poder dimensionar el impacto que tiene en la transmisión de creencias, valores, mensajes y significados que van más allá del mero acto de consumir para satisfacer necesidades individuales. Las modernas regulaciones de la publicidad estereotipada representan un avance en este sentido: dan cuenta del rol persuasivo de la publicidad en la reproducción, el refuerzo y la perpetuación de estereotipos de género y del impacto subliminal que tiene en la construcción y deconstrucción de la matriz cultural y simbólica que representa a los distintos géneros en nuestra sociedad.

91 Una experiencia positiva en Argentina surgida desde la sociedad civil en 2016 es la iniciativa de Pulicitarias.org, una comunidad de mujeres profesionales de la publicidad que tiene por objetivo incentivar la participación y el liderazgo de las mujeres en la industria. Por su parte, el Protocolo de Actuación Publicitaria no Sexista y Diversa de 2018 denuncia que en Argentina hay una ausencia casi total de mujeres al frente de las direcciones creativas de las agencias de publicidad.

92 En Argentina, el Protocolo de Actuación Publicitaria no Sexista y Diversa de 2018 denuncia que de los nueve planes de estudios de licenciaturas y tecnicaturas en publicidad relevados, ninguno contiene materias específicas referidas al enfoque de género en la comunicación ni tampoco este contenido está presente en otras asignaturas. Para un interesante estudio sobre quién y qué se enseña en las carreras de publicidad, diseño y marketing en Lima (Perú), véase Mendoza Cuéllar (2012), pp. 154-158.

93 En Argentina se han dado recientes casos de consumidores individuales que han expresado repudio en redes sociales y presentado reclamos frente a organismos del Estado denunciando publicidades estereotipadas. Un ejemplo es la publicidad de Carrefour Argentina para el día del niño 2018 que anunciaba juguetes diferenciados para ellos y ellas: niños campeones y constructores, y niñas cocineras y coquetas. Debido a la reacción en las redes sociales, Carrefour tuvo que retractarse, pedir disculpas y retirar la publicidad de los locales. 


\section{BIBLIOGRAFÍA CITADA}

Acciarri, Hugo y Tolosa, Pamela A. (2009). "La ley de defensa del consumidor y el análisis económico del derecho", en Picasso, Sebastián y VÁzQuez Ferreyra, Roberto A. (edit.), Ley de Defensa del Consumidor: Comentada y Anotada, (La Ley, t. II), pp. 1-65.

Akerlof, George A. y Shiller, Robert J. (2015). Phishing for phools. The economics of manipulation and deception (Princeton).

Alonso, Silvina A. (2015). "Género, estereotipos y violencia contra la mujer", Revista Furídica Do Cesuca, Vol. 2, No 4, pp. 149-157.

Arias, María Paula (2015). "Violencia simbólica", en Urrutia, Liliana A. B., PrunotTo, Mariana y Trucco, Marcelo (edit.), "La Protección Integral de las Mujeres Contra la Violencia de Género. Ley 26.485. Análisis a Nivel Nacional e Internacional", furis, pp. 370-380.

Arias, María Paula y Trivisonno, Julieta B. (2019). "Las prácticas abusivas del art. 26 del Anteproyecto de Ley de Defensa del Consumidor", en Santarelui, Fulvio G. y Chamatropulos Demetrio Alejandro (edit.), Comentarios al Anteproyecto de Ley de Defensa del Consumidor (La Ley), pp. 305-326.

Bar-Gill, Oren (2014). "Consumer transactions", en Zamir, Eyal y Teichman Doron (edit.), The Oxford Handbook of Behavioral Economics and the Law (Oxford University Press), pp. 465-490.

Barocelli, Sebastián (2016). "La regulación de la publicidad en el Código Civil y Comercial”, Revista de Derecho del Consumidor, Vol. 1, IJ-CCXI-180.

Chaher, Sandra y Pedraza, Virginia E. (2018). Violencia de género y políticas públicas de comunicación en Argentina: avances y retrocesos hasta 2017, en: http://www.fundeps. org/genero-comunicacion-2017/

Chamatropulos, Demetrio Alejandro (2019). Estatuto del consumidor comentado (2da. ed., La Ley).

Colín, Alma Rosa (2017). La desigualdad de género comienza en la infancia (Red por los derechos de la infancia en México).

Craig, R. Stephen (1992). "The effect of television day part on gender portrayals in television commercials: A content analysis", Sex Roles, Vol. 26, pp. 197-211.

Davidson, Darren (2017). Facebook Targets 'Insecure' to Sell Ads, en: https://www. theaustralian.com.au/business/media/facebook-targets-insecure-young-people-to-sell-ads 
Faur, Eleonor y Medan, Marina (2010). "Las masculinidades en los medios de comunicación social: decisiones públicas, consumos privados”, en Chaher, Sandra y Santoro, Sonia (edit.), Las Palabras Tienen Sexo. Herramientas Para un Periodismo de Género (Artemisa), pp. 55-72.

Femenías, María L. (2013). Violencias cotidianas (Ediciones Prohistoria).

Furham, Adrian y, Twiggy Mak (1999). "Sex-role stereotyping in television commercials. A review and comparison of fourteen studies done on five continents over 25 years", Sex Roles, Vol. 41, pp. 413-437.

García Beaudoux, Virginia (2015). "Influencia de la televisión en la creación de estereotipos de género y en la percepción social del liderazgo femenino. La importancia de la táctica de reencuadre para el cambio social", Ciencia Política, Vol. 9, pp. 47-66.

González y PARedes, Jordi (2004). Usos actuales del marketing sensual. Iconos femeninos en la publicidad de hoy (Granica).

Hanson, Jon D. y Kysar, Douglas A. (1999). "Taking behavioralism seriously: some evidence of market manipulation", Harvard Law Review, Vol. 112, pp. 14201572 .

Hernández, Dunia Etura y Fernández de la Vega, Sonia (2016). "Donde nace la violencia: desigualdad cotidiana en los medios de comunicación", en MARTín Jiménez, Virginia y Dunia E. Hernández (edit.), La Comunicación en Clave de Igualdad de Género (Fragua), pp. 23-40.

IbáÑEz, Carlos M. (2019). "La oferta y la publicidad en el anteproyecto de ley de defensa del consumidor", en Santareldi, Fulvio G. y Chamatropulos Demetrio Alejandro (edit.), Comentarios al Anteproyecto de Ley de Defensa del Consumidor (La Ley), pp. 349-364.

Jolls, Christine, Sunstein, Cass R. y Thaler, Richard (1998). "A behavioral approach to law and economics", Stanford Law Review, Vol. 50, pp. 1471-1550.

Kahneman, Daniel (2011). Thinking, fast and slow (Penguin).

Kahneman, Daniel, Knetsch, Jack L. y Thaler, Richard H. (1991). "The endowment effect, loss aversion, and status quo bias", Fournal of Economic Perspectives, Vol. 5, pp. 193-206.

Kemelmajer de Garluci, Aída R. (1996). "Publicidad y consumidores", Revista de Derecho Privado y Comunitario, No 5, pp. 85-141.

Korobkin, Russell B. y Ulen, Thomas S. (2000). "Law and behavioral science: removing the rationality assumption from law and economics", California Law Review, Vol. 88, ํㅜ 4, pp. 1.051-1.144.

Kuenzler, Adrian (2017). Restoring consumer sovereignty. How markets manipulate us and what the law can do about it (Oxford University Press).

Kuenzler, Adrián (2019). "Competition law enforcement on digital markets-lessons from recent EU case law", Fournal of Antitrust Enforcement, Vol. 7, pp. 249-78. 
Kysar, Douglas (2002). "Kids \& cul-de-sacs: census 2000 and the reproduction of consumer culture”, Cornell Law Review, Vol. 87, pp. 853-899.

LoRenzetti, Ricardo (2009). Consumidores (Rubinzal-Culzoni).

Melo, Andrea N. y Astorino, Julieta (2016). "Estereotipos de género en publicidades de productos dirigidos al público infantil en Argentina", Ánfora, Vol. 23, $\mathrm{N}^{\mathrm{o}}$ 40, pp. 17-50.

Mendoza Guéllar, Héctor (2012). "Entre el poder y el deber: la publicidad y su rol en la formación de estereotipos de género. Primeros apuntes", Correspondencias E̊ Análisis, No 2, pp. 131-164.

Mik, Eliza (2017). "Persuasive technologies: from loss of privacy to loss of autonomy", en Barker, Kit et al. (edit.), Private Law in the 21st Century (Hart Publishing), pp. 361-387.

Monge-Rojas, Rafael, Fuster-Baraona, Tamara, Garita, Carlos, Sánchez, Marta, Smith-Castro, Vanesa, Valverde-Cerros, Oscar y Colon-Ramos, Uriyoán (2015). "The influence of gender stereotypes on eating habits among costa rican adolescents", American Fournal of Health Promotion, vol. 29, No 5, pp. 303310 .

Pasquau Liaño, Miguel (1992). "Comentario al art. 8 LGDCU de 1984”, en Bercovitz, Rodríguez-Cano y Salas Hernández, Javier (edit.), Comentarios a la Ley General para la Defensa de Consumidores y Usuarios (Civitas), pp. 143-150.

Peral, Santiago J. (2019). "La buena fe y el abuso del derecho por parte de los proveedores", en Santareldi, Fulvio G. y Chamatropulos, Demetrio Alejandro (edit.), Comentarios al Anteproyecto de Ley de Defensa del Consumidor (La Ley), pp. 207-220.

Putruele, Martina (2019). "Estereotipos de género: el 76\% de las mujeres cree que las publicidades las muestran de manera anticuada", en https://www.infobae.com/tendencias/2019/06/03/estereotipos-de-genero-el-76-de-las-mujeres-cree-que-las-publicidades-las-muestran-de-manera-anticuada/

Rachlinski, Jeffrey J. (2011). "The psychological foundations of behavioral law and economics", University of Illinois Law Review, Vol. 2011, N 5, pp. 1675-1696.

Ramírez Barahona, Paola (2018). "La transformación de los estereotipos en la publicidad", en Chaher, Sandra (edit.), Argentina: Medios de Comunicación y Género ¿Hemos Cumplido con la Plataforma de Acción de Beijing? (Comunicación para la Igualdad Ediciones), pp. 26-42.

Santarelli, Fulvio G. (2016). "El contrato de consumo en el código civil y comercial de la nación”, en Calvo Costa, Carlos A. (edit.), Doctrina y Estrategia del Código Civily Comercial (La Ley), pp. 707-726.

SAFronova, Valeriya (2019). "Gender stereotypes banned in British advertising", en: https://www.nytimes.com/2019/06/14/style/uk-gender-stereotype-ads-ban. html 
SANTORO, Sonia (2007). "Publicidades y campañas. Lenguaje visual", en CHAHER, Sandra y SANtoro, Sonia (edit.), Las Palabras Tienen Sexo. Introducción a un Periodismo con Perspectiva de Género (Artemisa), pp. 173-188.

Santoro, Sonia (2018). "Protocolo de actuación publicitaria no sexista y diversa", en: http://soniasantoro.com/se-presento-protocolo-actuacion-publicitaria-no-sexista-diversa/

Stiglitz, Gabriel A. y Hernández, Carlos A. (2015). Tratado de derecho del consumidor (La Ley).

Suárez Villegas, Juan Carlos (2013). "El micromachismo en la publicidad. Nuevas estrategias para viejos estereotipos: 'mi marido me ayuda' y 'el elogio de la maternidad'”, Pensar la Publicidad, Vol. 7, N 2, pp. 239-251.

Susser, Daniel, Roessler, Beate y Nissenbaum, Helen F. (2018). "Online manipulation: hidden influences in a digital world", en: http://dx.doi.org/10.2139/ ssrn.3306006.

Specia, Megan (2019). "Siri and Alexa reinforce gender bias, U.N. finds", en: https:// www.nytimes.com/2019/05/22/world/siri-alexa-ai-gender-bias.htmlue

Tambussi, Carlos E. (2015). "La publicidad prohibida en el nuevo Código", La Ley, Vol. D, pp. 769-773.

Tversky, Amos y Kahneman, Daniel (1974). "Judgment under uncertainty: heuristic and biases", Science, Vol. 185, pp. 1124-1131.

Wajntraub, Javier H. (2017). Régimen jurídico del consumidor comentado (Rubinzal- Culzoni). 


\section{NORMAS CITADAS}

CEDAW: Convención sobre la Eliminación de todas las Formas de Discriminación Contra la Mujer del 18 de diciembre de 1979.

Brasil: Ley N 8.078 del 11 de septiembre de 1990, Defensa del Consumidor.

Argentina: Ley No 24.240 del 13 de octubre de 1993, Defensa del Consumidor.

Argentina: Ley No 24.430 del 15 de diciembre de 1994, Constitución de la Nación Argentina.

Argentina: Ley No 26.485 del 11 de marzo de 2009, Protección Integral a las Mujeres.

Argentina: Ley No 26.522 del 10 de octubre de 2009, Servicios de Comunicación Audiovisual.

Argentina: Ley No 26.618 del 15 de julio de 2010, Matrimonio Civil.

Argentina: Ley No 26.743 del 9 de mayo de 2012, Identidad de Género.

Argentina: Ley N²6.994 del 1 de octubre de 2014, Código Civil y Comercial de la Nación.

Argentina: Anteproyecto de Ley de Defensa del Consumidor del 6 de diciembre de 2018.

Argentina: Ley No 27.499 del 19 de diciembre de 2018, "Ley Micaela" o Ley de Capacitación obligatoria en género para todas las personas que integran los tres poderes del Estado. 